\title{
Factors affecting farmers' land tenure security after the implementation of rural land registration and certification program in Hulet Eju Enese district, Amhara region, Ethiopia
}

\author{
Gebrie Tsegaye \\ Department of Geography and Environmental Studies, College of Social Sciences and Humanities, \\ Samara University, P.O. Box - 132, Semera, Ethiopia.
}

Received 27 February, 2017; Accepted 24 March, 2017

\begin{abstract}
In Ethiopia, land tenure insecurity is one of the major factors that affect the productivity of smallholder agriculture and sustainable development. The present government of Ethiopia designed and implemented rural land registration and certification program in the four major regions to enhance the land tenure security of peasants. The aim of this study was to investigate factors that affect land tenure security of farmers after the implementation of the program in Hulet Eju Enese District, Amhara region. Identifying the main factors affecting land tenure security and investigating the extent of each factors were the specific objectives of the study. The research designs were both quantitative and qualitative research method and the data were collected by questionnaire and interview. Stratified, random and purposive sampling methods were employed to select sub districts, farmer households and key informants, respectively. Binary logistic regression model and narration were used as method of data analysis and interpretation. The result shows that from the stated factors, some of them still affect the land tenure security of the farmer households in the study area. Therefore, in the implementation of the second stage of the program, emphasis should be given to minimize the influence of those factors and to attain sustainable land use practice.
\end{abstract}

Key words: Land, tenure, security, registration, certification, rural, possession.

\section{INTRODUCTION}

Ethiopia is an agrarian country where agriculture plays a central role in the national economy and sustainable development. It supports as an employment area for more than $80 \%$ of the population, and 40 to $45 \%$ of the national GDP, it also contributes as a raw material for agro-industries, food security and foreign exchanges (Berhanu, 2006).

In the productivity of agriculture, land is the most important valuable natural resource. According to the World Bank (2007), in most developing countries, land

E-mail: gebrietsegaye@gmail.com.

Author agree that this article remain permanently open access under the terms of the Creative Commons Attribution License 4.0 International License 
accounts for between half and three-quarters of the national wealth and it is a fundamental input in agricultural production. Its function is directly linked to food security and livelihood. Furthermore, it is also used as a primary source of collateral for obtaining credit from institutional as well as informal providers (Dessalegn, 2004). In order to accelerate the sustainable development of agriculture, land needs appropriate policy and implementing agents. The basic policy issue to improve the productivity of land is tenure security; "the degree of confidence detained by the farmers that, they will not be illegally deprived of their land rights and economic benefits gained from it (Nazneen et al., 2005)".

Land tenure security is a critical issue to provide motivation to invest on the land, reduce and resolve land related disputes and to increase productivity (World Bank, 2007). Additionally, secure property rights protect individuals against expropriation by neighbors and other agents, as well as against the state (Dessalegn, 2004).

In the 1990s, the Ethiopian government admitted that land tenure insecurity in the country affects investment on land, aggravates land related disputes and affects agricultural productivity. Hence, in the federal proclamation (Proc No.89/1997), the four main regions of the country (Tigray, Amhara, Oromiya and SNNPR) have issued their region's specific land administration and use proclamation and commenced with land registration system. Then, Tigray region started the implementation of the program in 1998, while Amhara followed in 2003 and Oromiya and SNNPR a year later (Solomon, 2006).

In Amhara region, the program was started and implemented in two pilot districts; Gozamn and Dessie Zuria district in 2003. The regional government progress report indicated that the implementation of the program in the pilot districts could achieve its target significantly and decided to implement in all districts of the region since 2004 (Berhanu and Fayera, 2005; Berhanu Adugna, 2009. Therefore, the main objective of this study was to investigate factors affecting land tenure security after the implementation of rural land registration and certification program in Hulet Eju Enese district, Amhara National Regional State, Northwest Ethiopia.

\section{METHODS AND MATERIALS}

\section{Study site}

Hulet Eju Enese district is one among the 166 districts of Amhara National Regional State (HEEW, 2011). It is found in Misrak Gojjam administrative zone. It has 42 administrative sub district which is 40 rural and 2 urban. Hulet Eju Enese district is located at $10^{\circ} 40^{\prime \prime} \mathrm{N}$ to $11^{\circ} 10^{\prime \prime} \mathrm{N}$ and $37^{\circ} 46^{\prime \prime} 30^{\prime} \mathrm{E}$ to $38^{\circ} 9^{\prime \prime} \mathrm{E}$.

The study used both primary and secondary data sources for the achievement of the stated specific objectives. Map of the study area is produced in Figure 1. The primary data were collected by using questionnaires and farmers of the study area who have land and received "Book of Rural land possession" (the book provided to the farmers to assure their landholding rights) and key informant interviewees from farmers and experts are the main primary data sources of the study.
A stratified sampling technique was adopted to select the sample area for the achievement of the study. Within the current administrative structure, there are 40 rural sub districts in Hulet Eju Enese district. Based on agro-ecological division, these districts are stratified into Dega, Woina Dega and Kolla which is 12, 20 and 8 sub districts in number, respectively. By using random sampling method, ten percent from each agro- climatic regions were selected, which means 1, 2 and 1 sub districts from Dega, Wina Dega and Kolla, respectively. These sub districts are Chak, Atsede Birhan, Hezbe Selam and Gedam Abo.

List of household $(\mathrm{HH})$ members of each sub districts that received "Book of Rural Land Possession" employed as a sample frame. The list was obtained from the sub districts land administration offices and the total number of households in the four sub districts would be taken as, the sample frame which was 1275. The researcher selected ten percent randomly from each sub district which was a total farmer $\mathrm{HHs}$ of 128 , this was the sample that the researcher used to collect data by using questionnaire. In addition, interviews were also applied with district officials, each sub district land administration experts and selected key informant farmers. The data were analyzed by using binary logistic regression model. For the operation of this task, SPSS Version 20 (Statistical Package for the Social Science) software were employed. Different models were used to estimate the relationship between the dependent and explanatory variables. In this research, the dependent variable, land tenure security would be treated as dichotomous. For the analysis of this type of dependent variables Hosmer and Lemeshew (1989) pointed out, binary logistic regression (logit) is more important than the others. Because, it is an extremely flexible and easily usable model (Greene, 2003).

\section{Definition and measurement of variables}

The dependent variable was land tenure security (Its) and ten independent variables were used to estimate whether land tenure security is related to these explanatory variables or not. These were age of the household heads ( $\mathrm{HHHs}$ ), sex of the $\mathrm{HHHs}$, educational status of the $\mathrm{HHHs}$, family size and land holding size (Holden and Hailu, 2001), and fear of future land redistribution, absence of clear justice system to settle land related disputes, different government body interventions, lack of experience and knowledge in the local land administration experts and lack of alternative means of livelihood (Bruce et al., 1994; Desalegn, 2004).

\section{Age of the household head}

Age of the household head may have its own effect on the land tenure security of farmers. In the past, farmers who have influence on the community have been perceived to be secured than the others. The oldest farmers lose their influence in the community and may feel more land tenure insecurity than the others groups (Holden and Hailu, 2001). Therefore, the youngest of the household head was more secure than the oldest.

\section{Sex of the HHHs}

There is a long history that, male headed $\mathrm{HHs}$ has more respect in the community (Holden and Hailu, 2001). The assumption was female headed households were more insecure about their tenure.

\section{Educational status of the $\mathrm{HHHs}$}

When the level of education is high, the more they know about the land rights and duties in the proclamation and users book. 


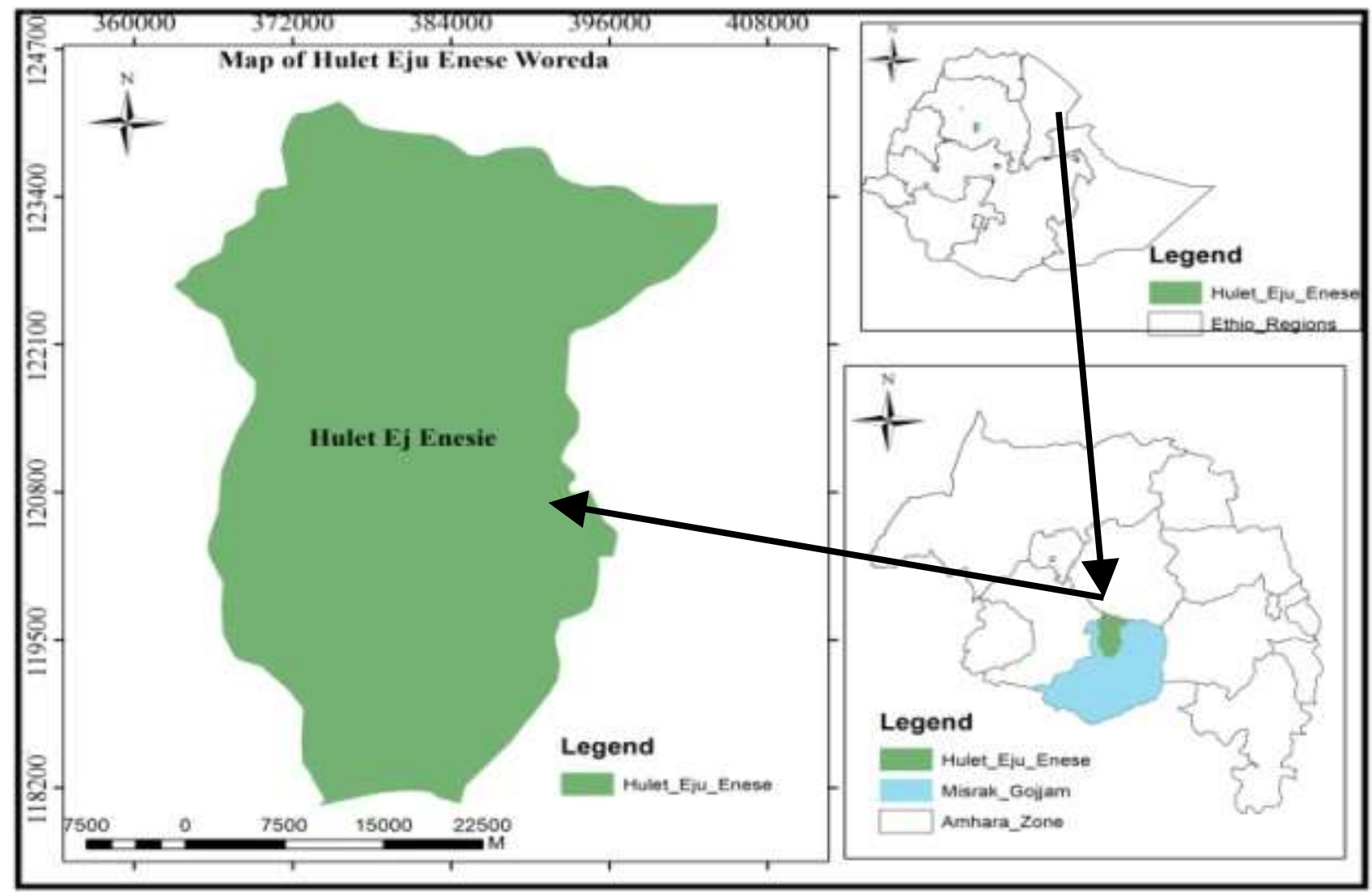

Figure 1. Map of the study area. Source: Constructed by author (2013).

Therefore, literate farmers were feeling more tenure security than the illiterate farmers.

\section{Family size of the respondents}

As almost all of the farmers in the district are depends on agricultural outputs alone, a household with more family size may be insecure by thinking of what will happen to their family in the future.

\section{Land holding size}

Farmers who have more land than others may fear losing their land to the new comers. Households with larger relative farm size feel more tenure insecure than those who have relatively less land (Holden and Hailu, 2001). Therefore, largest landholding size was the other determinant factor that affects tenure security.

\section{Fear of future land redistribution}

In Ethiopian, history land redistribution was conducted so many times and farmers always fear not to lose their cultivated land (Dessalegn, 2004). Especially, in Amhara region, redistribution is a recent phenomenon which is conducted in 1996/7, by memorizing it, farmers of the region fear there may be land redistribution soon (Samuel, 2006). Therefore, fear of future land redistribution was a determinant factor that aggravates land tenure insecurity of farmers after the implementation of rural land registration and certification program.

\section{Absence of clear justice system to resolve land related disputes}

As stated by Dessalegn (2004), during the imperial regime, the only responsible body who listen to any land related disputes was the local courts. However, these courts were highly corrupt and always stand at the side of the rich and powerful peoples. They do not give attention to the voice of the poor. Derg eliminated this court and give the responsibility to peasant associations. While the present government established social courts at the sub district level. But they do not have enough power to listen to land dispute cases. Hence, except simple cases that are solved by the sub district land administration experts in collaboration with committees, most of the land related dispute cases come to the district courts, most of the time in relation to distance, this is time consuming and costly to the farmers and the district court has not enough knowhow on each parcel of farmers land and sometimes the justice system that used to settle land related disputes are not clear (Dessalegn, 2009). It was considered as one of the main factors that affect farmers' perceptions of land tenure security after the implementation of the program.

\section{Different government body interventions}

There are different government bodies that intervene on land matters. These as development agents (DA), the sub district councils, officials from agricultural offices and environmental protection and land administration office. They may pass any decision that may affect the individuals secure land rights.

Therefore, it was one of the main factors that affected land tenure 
Table 1. Overview and definition of variables included in the binary logistic regression model.

\begin{tabular}{ll}
\hline Variables code & Description \\
\hline Lts & Land tenure security; $0=$ yes (secure), $1=$ no (insecure) \\
hhage & Age of the head of the household... Continuous variable \\
hhsex & Sex of the head of the household; male=0, female=1 \\
famsize & Family size of the household; Continuous variable \\
landhsize & Total farm landholding size in hectare; Continuous variable \\
hhedustatus & Educational status of the hhhs; $0=$ literate, $1=$ illiterate \\
Fflr & Fear of future land redistribution; $0=$ no, $1=$ yes \\
Acjs & Absence of clear justice system to settle land related disputes; $0=$ no, $1=$ yes \\
Dgbi & Different government body interventions; $0=$ no, $1=$ yes \\
Leklae & Lack of experience and knowledge of the land administration experts; $0=$ no, $1=$ yes \\
Laml & Lack of alternative means of livelihood; $0=$ no, $1=$ yes \\
\hline
\end{tabular}

security after the intervention.

\section{Lack of experience and knowledge by the sub district land administration experts}

Local land administration officials especially district and sub district officials are ignorant of the policy and legislations they are supposed to administer (Dessalegn, 2009). Therefore, it was also considered as one of the factors that affect the land tenure security of farmers after the implementation of the program in the study area.

\section{Lack of alternative means of livelihood}

As agriculture is the only means of livelihood for most of the Ethiopian farmers, if there is any problem in relation to this sector, all the life of the household members will be in danger (Bruce et al., 1994). So, lack of alternative means of livelihood was also the other main factor that affects the land tenure security of the farmers of the district after the implementation of program.

\section{Regression model specification}

The dependent variable land tenure security was a dummy variable. The question raised for the respondents "Is your sub district farmer's land tenure security increase after the book of rural land possession"? The dichotomy value of this dependent variable is indicated as, zero if the farmers replay "no" (not secured) and one if they replied yes (secured).

Ten independent variables were used to see whether or not these were factors that affect land tenure security of the study area farmers after the implementation of the program. These were age of the household heads, sex of the household heads, educational status of the household heads, family size and land holding size (Holden and Hailu, 2001), and fear of future land redistribution, absence of clear justice system to settle land related disputes, different government body interventions, lack of experience and knowledge of sub district land administration experts and lack of alternative means of livelihood (Bruce et al., 1994; Desalegn, 2004). The form of binary logistic regression model with multiple covariates is indicated in Gujarati (2004) as:

$Z_{i}=\beta_{0}+\beta_{1} x_{1}+\beta_{2} x_{2}+\beta_{3} x_{3} \ldots \ldots \ldots \ldots \ldots \ldots+\beta_{k} x_{k}$

Where $Z_{i}$ Is the dependent variable; which is determined by the independent variables $x_{1}, x_{2}, x_{3} \ldots . . x_{k}$ and $\beta_{0}$ the constant term and the remaining $\beta$ 's were the extents to which each independent variables affects the dependent variable. Therefore, the general model of the binary logistic regression for this study was illustrated as:

Its $_{i}=\beta_{0}+\beta_{1}$ hhage $_{i}+\beta_{2}$ hhsex $_{i}+\beta_{3}$ famsize $_{i}+\beta_{4}$ edustatus $_{i}+\beta_{5}$ landhsize $_{i}+\beta_{6}$ fflr $_{i}+\beta_{7}$ acjs $_{i}+\beta_{8}$ dgbi $_{i}+\beta_{9}$ leklae $_{i}+\beta_{10}$ laml $_{i}$

Where, Itsi = land tenure security, hhhage = age of the household head, hhhsex = sex of the, famsize = family size of the household, edustatus $_{i}=$ educational status of the household head, landhsize $e_{i}=$ land holding size of an individual $i$, fflri = fear of future land redistribution, acjsi = absence of clear justice system to settle land related disputes, dgbii $=$ different government body interventions, leklaei = lack of experience and knowledge in the kebele land administration experts and lamli = lack of alternative means of livelihood.

\section{RESULTS AND DISCUSSION}

For the binary logistic regression model, ten explanatory variables (seven dummy and three continuous) were included in the model. The summary of the dependent and explanatory variables that influence the farmer's land tenure security were presented in Table 1.

The researchers asked the respondents whether the above explanatory variables were factors that affect the land tenure security of the communities in the study area after the program or not and the responses were yes or not. For the response, no is coded as 0 and yes coded as 1. It helps to investigate whether the variables are still factors that affect the land tenure security rights of the farmers in the specified area or not.

\section{Test for goodness of the fit- Hosmer and Lemeshow test}

Hosmer and lemeshow test is one of the methods that help to measure the goodness of fit of the model. If the $\mathrm{H}$ $\mathrm{L}$ goodness-of-fit test statistic is greater than 0.05 , it is a well-fitting model. As indicated in Table $2, \mathrm{H}-\mathrm{L}$ statistic 
Table 2. Hosmer and Lemeshow test.

\begin{tabular}{lccc}
\hline Step & Chi-square & Df & Sig. \\
\hline 1 & 9.058 & 8 & .337 \\
\hline
\end{tabular}

has a significance of 0.337 , this is greater than 0.05 which means the model was quite a good fit.

The final important table that must be interpreted in this model to get the final result was "variables in the equation". Table 3 indicates the variables and their significance level to the dependent variable land tenure security, coefficients, standard errors, Wald test, significance and $\operatorname{Exp}(\mathrm{B})$.

Among the ten explanatory variables included in the model, five variables had a significant level in affecting the land tenure security rights of farmer households after the implementation of rural land registration and certification program. These variables includes, age of the household head, household head educational status, family size, land holding size, fear of future land redistribution and lack of experience and knowledge of sub district land administration experts.

Except lack of experience and knowledge of the sub district, land administration experts which was significant at $5 \%$, the other variables were significant at $10 \%$ and except family size, the coefficient of all the significant variables was in a negative sign which indicates these variables affect the dependent variable land tenure security negatively. The other variables were insignificant on their effect on land tenure security presently in the study area.

\section{Age of the household head}

As indicated in the model, age of the household head was significant at $10 \%$ and the coefficient was a negative sign that means when the age of the household head increases the feeling of land tenure security is decreased by the $\operatorname{Exp}(\mathrm{B})$ value which was 0.916 . This could be due to the oldest farmers believe loss of influence in the power of the community than the youngest. This was correctly proved by Holden and Hailu (2001) findings and after the intervention, old aged households are more insecure about their land holding.

\section{Educational status of the household heads}

Educational status of the household head also significant at $10 \%$ and the coefficient sign was negative, which means it affects the land tenure security of farmers after the implementation of rural land registration and certification program in Hulet Eju Enese woreda, negatively. The generalization is that, educated farmers had confidence on their land holding rights than the uneducated farmers (Dessalegn, 2009).

\section{Family size of the household}

Family size of the households was also a significant factor that affects the land tenure security of the landholders in the study area. As indicated by the model, its effect was positive because the coefficient sign was positive. This is mostly contradicting with the assumption that, when the number of family increases, farmer's perception of land tenure security was decreased (Holden, 2010; USAID, 2007). Because, farmers whose family are large in number, they think for their future family life and fear of losing land than those that have small number of families. But, it may be also due to wanting future land redistribution.

\section{Fear of future land redistribution}

Presently, there are two arguments in relation to fear of future land redistribution in the farmers of the study area; one believe that land redistribution will not occur in the future and the other believe that due to population growth and increment of unemployment rate, there will be future land redistribution.

Farmers who have more land now, fear future land redistribution to lose their holdings. Because, if land redistribution will occur in the future; the first losers may be those who have more land now. In other ways, farmers who have small plots of land did not fear future redistribution to lose their land. Because they know their land is small and they also hope that, their children may get land by the new redistribution.

As Hosena (2010) research result in Tigray region stated, many of the farmers have a small plots hoped to gain land by new land redistribution in the future. This is also true in Hulet Eju Enese district farmers who have small plot of land relative to others or who have no land by his/her name hoped to get agricultural land by the future land redistribution and they wants to see land redistribution in the near future.

Fear of future land redistribution was not the only factor a farmer fear of losing his/her land. For instance: As the expert of Atsede Birhan sub district stated that:

"Satellite town is planned to be established and farmers fear of losing their land by the establishment of this town and they always ask me about their future in relation to the town, farmers also fear of losing land in relation to cadastral surveying. These farmers may be those who registered their land in a false size in the first stage of the program".

Table 4 indicates that, more than $40 \%$ of the total respondents fear future land redistribution in the four sampled sub districts. That means, important number of 
Table 3. Variables in the equation.

\begin{tabular}{llccccc}
\hline & B & S.E. & Wald & Sig. & Exp(B) \\
\hline & Hhage & -0.088 & .044 & 3.936 & $0.047^{\star *}$ & 0.916 \\
& hhsex(1) & -0.118 & 1.026 & 0.013 & 0.908 & 0.889 \\
& Famsize & 0.604 & 0.270 & 4.996 & $0.025^{\star *}$ & 1.830 \\
Step 1 $^{\mathrm{a}}$ & hhhedustatus(1) & -1.431 & 0.791 & 3.272 & $0.070^{\star * *}$ & 0.239 \\
& Landhsize & 0.910 & 0.686 & 1.759 & 0.185 & 2.486 \\
& fflr(1) & -2.095 & 0.843 & 6.170 & $0.013^{\star *}$ & 0.123 \\
& acjs(1) & -0.519 & 0.702 & 0.547 & 0.459 & 0.595 \\
& dgbi(1) & 0.297 & 0.713 & 0.173 & 0.677 & 1.346 \\
& leklae(1) & -2.926 & 1.019 & 8.236 & $0.004^{\star}$ & 0.054 \\
& laml(1) & 1.870 & 1.510 & 1.533 & 0.216 & 6.487 \\
& Constant & 0.659 & 2.237 & 0.087 & 0.768 & 1.933 \\
\hline
\end{tabular}

a. Variable (s) entered on step 1: hhage, hhsex, famsize, hhedustatus, landhsize, fflr, acjs, dgbi, leklae, laml. *, ${ }^{* *}$ and ${ }^{* * *}$ significant at 1,5 and $10 \%$.

Table 4. Fear of future land redistribution.

\begin{tabular}{llcccccccc}
\hline Assessment tools & \multicolumn{2}{l}{ Sub districts } & \multicolumn{2}{c}{ Atsede Birhan } & \multicolumn{2}{c}{ Hizbe Selam } & \multicolumn{2}{c}{ Gedam Abo } & \multicolumn{2}{c}{ Chak } \\
\cline { 2 - 10 } & Responses & $\mathbf{F}$ & $\%$ & $\mathbf{F}$ & $\%$ & $\mathbf{F}$ & $\%$ & $\mathbf{F}$ & $\%$ \\
\hline Do you fear future & Yes & 7 & 46.7 & 18 & 42.9 & 11 & 39.3 & 8 & 34.8 \\
land redistribution & No & 8 & 53.3 & 24 & 57.1 & 71.7 & 60.7 & 14 & 60.9 \\
& No response & & & & & & & 1 & 4.3 \\
\hline
\end{tabular}

Source: Survey data, 2013.

respondents still think land redistribution will be conducted in their area and some of them fear losing their lands. The logistic regression model results also indicate fear of future land redistribution was significant at $10 \%$ with a negative sign coefficient with land tenure security. That means a farmer who believes land redistribution will be conducted in the future become more insecure than those who did not fear future land redistribution.

Therefore, as both the qualitative and quantitative result indicates fear of future land redistribution is still a factor that affects the land tenure security of farmers in Hulet Eju Enese district and it supports Deininger et al. (2008) findings that conclude the implementation of the program reduced fear of future land redistribution but did not overcome it.

\section{Absence of clear justice system to settle land related disputes}

The regression result indicated that absence of clear justice system to resolve land related disputes was not a significant determinant of land tenure security after the implementation of the program even if its coefficient was negative. This conclusion was the same with the following qualitative responses from both the land administration experts and farmer respondents.
As head of the district environmental protection land administration and use office described, in the past, the justice system could shape to wrong decision by the influential groups, because, there was no legal document that indicates the right user of a certain land. After the implementation of the program, the user's book is the guarantee of farmers to get appropriate decision in relation to land related disputes. Even if, corruption is still aggravated in different forms in the district, absence of clear justice system to resolve land related disputes is not a factor that affects land tenure security of farmers. During the interview with farmers, all farmers do not think absence of clear justice system is a factor that affects their land tenure security rights; a farmer from Chak sub district stated that:

"I know my rights and obligations and my land is also registered and I received the book holding used as a witness of my user rights, now I do not fear absence of clear justice system may affect my land tenure security right, because, if something is happening arbitrarily in relation to my user right, the book will be used as a guarantee".

Similarly, experts also assert that, absence of clear justice system is not factor that affect the land tenure security of farmers presently in the district. Because, 
farmers have various options to report the problem they are faced in different situations in relation to their user rights. First, a farmer goes to the sub district land administration committees, sub district land administration experts to get a solution for their problem. If they are not happy with the committee and expert decision, they report their problem to the district environmental protection, land administration and use office or the court. Therefore, absence of clear justice system to resolve land related disputes is not a long factor that affects the security rights of farmers in Hulet Eju Enese district after the implementation of rural land registration and certification program.

\section{Lack of experience and knowledge in the sub district land administration experts}

According to the head of the district environmental, protection land administration and use office lack of knowledge and experience in both the district and sub district land administration experts affect the security right of farmers directly or indirectly. Especially, sub district land administration experts are not willing to stay on their work as it is remote rural areas and when they got some options, they withdraw from their job. This creates always to lead by new land administration experts.

Additionally, there is not enough trained students in rural land administration departments and most of the employs are from law and other related departments given in different colleges as a diploma level. During the startup of the program, the job is covered by the farmers selected as land administration committees and at that time, some farmers fear, another way of injustice on their land holding like the 1996/7 land redistribution employed in the region. However, after a year, the district environmental protection, land administration and use office employed sub district land administration experts and it is open for any department students who have diploma in a known college and this creates lack of awareness or experience on the sub district land administration experts.

The regression result also indicates that lack of experience and knowledge of the sub district land administration experts is a significant variable at $5 \%$ that affect the land tenure security of farmers. Negative sign of the coefficients indicates the negative effect of the variable on the land tenure security of the landholders. Therefore, lack of knowledge and experience in the sub district land administration experts is still one of the factors that influence the security rights of smallholder farmers in the district.

\section{Lack of alternative means of livelihood}

As the experts stated that, farmers could not have alternative livelihood strategies in addition to agriculture.
If they face a problem on their agricultural practice, their life will be in danger. Therefore, lack of alternative livelihood strategies is one factor that needs emphasis to increase farmers land tenure security. Even, this also forced farmers to fear facing environmental calamities such as lack of seasonal rainfall and climate change.

Farmers replied that, lack of alternative means of livelihood is a factor that affects their land tenure security. People fear losing land because the land is their only assets, their life were depend on it and most of them replied this is the major factors that forced them to think about their future security. Contrary, some farmer respondents also replied that, presently, some farmers who accumulate capital start another means of livelihood to support their agricultural productivity. For instance, there are farmers who starts trade activities in the rural area by creating connection with the town merchants and they are beneficiaries. These groups conclude, lack of alternative means of livelihood is not a factor that affects the security rights of farmers in the district and this response is also supported by the regression model. It indicates lack of alternative means of livelihood is not a significant factor that affects land tenure security rights of farmers.

\section{Different government body interventions}

Different government body intervention is not significant in the model by affecting the land tenure security of farmer households in the study area. Farmers who participate in the interview process also stated that, different government bodies who intervene in different agricultural activities do not affect their land tenure security rather it plays its own role in the productivity of their agriculture. A farmer from Chak sub district stated that:

"There are different government officials in our sub district who contacted us for different reasons. For instance, presently there are three development agents (DAs) who are responsible for land, forest and livestock production, one sub district manager, one sub district environmental protection, land administration and use office expert, land administration committees and different administrative bodies. But, their interventions on different issues have no effect on the land tenure security of the farmers"

Therefore, the above interpretation indicated that the intervention of different government bodies on the agricultural activities do not affect farmers land tenure security rather it helps to increase their agricultural productivity.

\section{Fear in relation to compensation}

Even if the proclamation stated that, if the government 
took farmers land for development project, appropriate compensation will be provided to the users in type (land equivalent to the land they lose) or in cash. But, there are a lot of challenges in the implementation processes of compensation. The best example for this is, during my observation in the sampled sub districts, there is a concert road constructed from the district capital city Motta to Atsede Birhan sub district and it was observed that, the road crosses on the agricultural lands of many farmers. The sub district land administration experts explained that, there is a very complex situation in the compensation process.

When the researcher contact farmers and asked whether they got proper compensation or not, some farmers got compensation even if they claimed that it is not proper in relation to the land they lose and there are also farmers that did not get any compensation. A farmer during the interview process stated that:

I lost some portion of land by the construction of the road and I did not get any compensation for the land, I always reported to the sub district land administration office. But, the expert did not give good response.

The sub district environmental protection, land administration and use expert replied to this as:

"The sub district environmental protection, land administration and use expert there, when the farmers lost their land made a great mistake, he must facilitate the implementation of the compensation process. Presently, there is no document that indicates how many hectares of land farmers lose and also the compensation during the time when the road was constructed and now also, a great variation of these are the main constraints to pay the compensation and I always report to the district and the district announce the losers will get the compensation after the land they lose is measured in a short period".

The above case indicated that getting proper compensation to the land they lose affect the land tenure security of the farmers. Farmers who lose their land by the construction of the new road are normally insecure in relation to compensation and the other farmers around these groups also fear of getting proper compensation, if the government took their land for development project.

\section{Conclusion}

The implementation of rural land registration and certification program is a good initiatve taken by the government of Ethiopia to improve the land tenure security of farmer households and to boost the productivity and sustainable development of the main economic activity of the country agriculture. Presently, the first stage of the intervention which is providing land holding book has been completed. The intervention improves the feeling of the farmers in relation to land tenure security as compared to the previous time. However, there are still factors which aggravates farmers felling of land tenure insecurity such as age of the household head, household head educational status, land holding size, fear of future land redistribution and lack of experience and knowledge of sub district land administration experts. Therefore, the concerned bodies should give emphasis to reducing the influence of these factors in the second stage of the intervention. Especially, by improving farmers awareness about the role of the program and by providing intensive training to the land administration experts of the district, sustainable land use practice should be attained.

\section{CONFLICT OF INTERESTS}

The author has not declared any conflicts of interest.

\section{REFERENCES}

Berhanu A, Fayera A (2005). Land Registration in Amhara Region, Ethiopia :Securing Land Rights in Africa. Research report 3, iied, RussellPress, Nottingham, UK.

Berhanu A (2006). Effective Aid for Small Farmers in Sub-Saharan Africa: Southern Civil Society Perspectives, for the Canadian Food Security Policy Group, Ethiopia case study, Addis Ababa. Ethiopia.

Berhanu A (2009). The Effect of land Certification on Land Tenure Security: A case Study in Libo -KemkemWoreda, Amhara Region. Addis Ababa University Ethiopia.

Bruce W, Hoben A, Dessalegn Rahmato (1994). After the Derg: an assessment of rural land tenure issues in Ethiopia. Land Tenure Center, University of Wisconsin-Madison, and the Institute of Development Research, Addis Ababa University. Ford Foundation.

Dessalegn R (2004). Searching for tenure security: The Land System and New Policy Initiatives in Ethiopia, FSS Discussion No. 12. FSS, Addis Ababa. Ethiopia.

Dessalegn R (2009). Peasants and agrarian reforms: The unfinished quest for secure land rights in Ethiopia and Land rights and tenure security: Rural land registration in Ethiopia, In Ubink et.al.

Dessalegn R (2009). The Peasants and the State: Studies in agrarian change in Ethiopia 1950s - 2000s. Addis Ababa University Press, Addis Ababa. Ethiopia.

Federal Democratic Republic of Ethiopia (1997). Federal Rural Land Administration Proclamation. Proclamation No. 89/1997. Addis Ababa, Ethiopia.

Federal Democratic Republic of Ethiopia (2005). Federal Democratic Republic of Ethiopia Rural Land Administration and Land Use proclamation. Proclamation No. 456/2005. Addis Ababa, Ethiopia.

Green J (1987). Evaluating the Impact of Consolidation of Holdings Individualization of Tenure and Registration of Title: lessons from Kenya. Land tenure center paper 192.University of WisconsinMadison, Madison

Greene (2003). Econometrics Analysis: New York University. MacMillan Publishing Company

Hulet Eju Enese Woreda (2012). Agricultural Office Annual reports on the agricultural production of The Woreda, from 2006/7 - 2011/12. Bahir Dar. Ethiopia

Holden D, Hailu Y (2001). Land Redistribution, Tenure Insecurity, and Intensity of Production: a study of farm households in southern Ethiopia, International Food Policy Research Institute, CAPRi working paper No. 21. Washington, D.C. 
Nazneen K, Cotula L, Hilhorst T, Toulmin C, Witten W (2005). Can land registration serve poor and marginalized groups? Summary report: Securing Land Rights in Africa, Russell Press, Nottingham, UK

Solomon A (2006). Land Registration System in Ethiopia: Comparative Analysis of Amhara, Oromia, SNNP and Tigray Regional States.In Solomon et.al, pp. 165- 18
World Bank (2007). Land Administration Reform: Indicators of Success and Future Challenges, Agriculture and Rural Development Discussion Paper 37, the International Bank for Reconstruction and Development/the World Bank.

USAID (2007). Land Tenure and Property Rights: Volume 1 Framework, ARD, Burlington, VT 05402.Vermont, USA. 